\title{
Conceptualising Violence at Work Through A Gender Lens: Regulation and Strategies for Prevention and Redress
}

\author{
Katherine Lippel*
}

\begin{abstract}
Violence against women is notoriously pervasive and has been studied at length. Surprisingly less is known about the different facets of violence to which women are exposed at work. This article presents findings from a working paper commissioned by the Gender, Equality and Diversity Branch of the International Labour Organization to provide an overview of literature on occupational violence, from a broad range of disciplinary perspectives, including both conceptual papers and descriptions of regulatory frameworks from around the world. It first looks at definitions of workplace violence, including physical, psychological, sexual and discriminatory violence, including harassment, as well as workplace related intimate partner violence. It then turns to determinants of occupational violence, including psychosocial risk factors and structural violence. A discussion of the importance of using a gender lens to understand occupational violence and its roots concludes the conceptual section. Finally, the article presents different regulatory approaches to the prevention of occupational violence including both international and national instruments, again examined through a gender lens. It presents the case, in conclusion, for an integrated regulation of violence at work in
\end{abstract}

*University of Ottawa,klippel@uottawa.ca. 
order to maximize uptake of rights and effectiveness of prevention measures while promoting violence free workplaces for men and women.

Keywords: Occupational Violence, Gender, Regulation, Prevention, Work

\section{Introduction}

Violence against women is notoriously pervasive and has been studied at length. Surprisingly less is known about the different facets of violence to which women are exposed at work. In the context of the International Labour Organization's (ILO) women at work centenary initiative and also to inform the preparations for the discussion of a possible international convention and recommendation on violence and harassment in the world of work, the Gender, Equality and Diversity Branch of the International Labour Organization commissioned a working paper to provide an overview of literature on occupational violence, drawn from a broad range of disciplinary perspectives, including both conceptual papers and descriptions of regulatory frameworks from around the world. The report, ${ }^{1}$ which builds on the 2006 ILO publication on violence at work, ${ }^{2}$ considered literature in English, French, and Spanish. It provided a portrait of various categories of occupational violence and examined the prevalence of these different categories, in different countries, viewed through a gender lens. It then described different regulatory approaches including binding and nonbinding initiatives, ${ }^{3}$ again viewed through a gender lens.

Workplace sexual violence, and sexual harassment in particular, have received attention in the literature and in regulatory strategies, but other types of violence to which women are disproportionally exposed either at work, because of the nature of their work, or while they travel to and

\footnotetext{
1 This article is based on Katherine Lippel, 'Addressing Occupational Violence: An Overview of Conceptual and Policy Considerations Viewed Through a Gender Lens' (2016) ILO Working Paper No. 5/2016

<http://www.ilo.org/gender/Informationresources/Publications/WCMS_535656/lang-en/index.htm> accessed 24 April 2016.

${ }^{2}$ Duncan Chappell and Vittorio DiMartino, Violence at Work ( $3^{\text {rd }}$ ed, ILO, 2006).

3 Teresa Fajardo, 'Soft Law' in Oxford Bibliographies in International Law

<http://www.oxfordbibliographies.com/view/document/obo-9780199796953/obo9780199796953-0040.xml> accessed 24 April 2016. For a discussion of corporate social responsibility and the human dignity of workers, see Isabelle Martin, 'Corporate Social Responsibility as Work Law? A Critical Assessment in the Light of the Principle of Human Dignity' (2015-2016) 19 Canadian Labour \& Employment Law Journal 255.
} 
from work, are less often addressed through a gender lens, and as a result, regulatory initiatives for promoting prevention and providing redress are less often conceptualized using a gender-sensitive analysis. This is a missed opportunity for crafting rules and practices that meet the needs of working women around the world.

The purpose of this article is to provide an overview of the findings of the report and to focus on priority strategies to ensure a better future for women at work. While it is hoped that the article will inform priority setting for discussions at the ILO, it is important to note that it does not seek to describe best practices in workplaces, best language in collective agreements or model voluntary standards. It does, however, include descriptions of some international and national regulatory approaches. The material is presented in two sections: the first describes the concepts and prevalence of various forms of occupational violence, prevention and intervention strategies discussed in the literature, and implications for women at work; the second provides an overview of national and international regulatory frameworks and raises questions as to the strengths and weaknesses of these frameworks from the perspective of working women.

\section{Conceptualising Workplace Violence}

This section explores various forms of workplace violence from a conceptual perspective and then applies a gender lens to identify intervention strategies.

\section{A. Definitions of Workplace Violence}

Workers are subjected to a myriad of forms of violence including physical violence, psychological violence (including harassment and bullying as well as verbal abuse), sexual violence (including sexual harassment and assault), other forms of discriminatory harassment, criminal violence, intimate partner violence related to the workplace, and technology-based violence including cyber-bullying. These categories are not mutually exclusive, but each raises challenges needing to be addressed. The relationship between the target of violence and the perpetrator is, of course, relevant. Violence can come from external sources, as in the case of robberies, external sources within the workplace, such as patients or school children, or internal sources, such as supervisors, colleagues or subordinates. With regard to internal violence, when it occurs between colleagues it is referred to as horizontal violence, while violence between 
different levels of the organisational hierarchy is referred to as vertical violence.

\section{(i) Physical Violence}

The World Health Organization (WHO) and the ILO defined physical violence in a joint questionnaire developed to study violence in the healthcare sector as 'the use of physical force against another person or group that results in physical, sexual or psychological harm, which includes, among others, beating, kicking, slapping, stabbing, shooting, pushing, biting and pinching'. ${ }^{4}$ Intention is not part of the definition, so that it includes not only behaviour that would be considered as a crime, but also acts by "perpetrators" who are not criminally liable for this type of behaviour, such as children, psychiatric patients, or residents of long term care facilities suffering from dementia.

In the United States, workplace homicide ranks very high in the statistics on work-related deaths for women, although this is less true for men. Due to a relatively segregated labour market, men are more likely to occupy jobs exposing them to other causes of work related fatalities. However, murder in the workplace, sometimes involving intimate partner perpetrators, has often been the first or second cause of workplace death for women in the U.S. in recent years. ${ }^{5}$

Physical violence committed by patients or students is often 'normalized' in the workplace, perceived to be part of the job, ${ }^{6}$ and in cases involving young children or legally incompetent adults it is highly unlikely that the criminal law would be applied. This said, in some countries, like the United States, ${ }^{7}$ violent crime is the primary focus of the literature on occupational violence, and the problems are

\footnotetext{
${ }^{4}$ ILO et al, 'Workplace Violence in the Health Sector: Country Case Studies Research Instruments' (2003)

<http://www.who.int/violence_injury_prevention/violence/interpersonal/en/WVquesti onnaire.pdf $>$ accessed 28 May 2018.

${ }^{5}$ The US Bureau of Labor Statistics reports that in 2014, among the workplace homicides in which women were the victims, the greatest share of assailants were relatives or domestic partners (32 percent of those homicides). In workplace homicides involving men, robbers were the most common type of assailant (33 percent). US Bureau of Labour Statistics, 'Census of Fatal Occupational Injuries Summary: 2016' <http://www.bls.gov/news.release/cfoi.nr0.htm> accessed 21 February 2016.

${ }^{6}$ This may affect reporting practices in surveys on occupational violence. See Markku Heiskanen, 'Violence at Work in Finland: Trends, Contents and Prevention' (2007) 8(1) Journal of Scandinavian Studies in Criminology and Crime Prevention 22.

7 The US Bureau of Labor Statistics reports that, in 2014, 749 occupational deaths were attributable to 'violence and other injuries by persons or animals'. The number of workplace homicides was about the same as the total in 2013; in 2015 the figures rose by 2\%. US Bureau of Labour Statistics (n 5).
} 
conceptualized in the criminological literature on crime prevention more often than in that relating to occupational health.

A detailed study of criminal victimization in the workplace in Canada found that 37 per cent of violent workplace incidents had been reported to the police, and that male victims were much more likely than women to report to the police. The study suggests that this might be explained by the fact that men were more likely to have suffered injuries than women, and that 'women were more often victims of sexual assault, which has the lowest reporting rate to police'. ${ }^{8}$ Among the cases of workplace violence where the perpetrator was known to the victim, the perpetrator was a co-worker in 18 per cent of incidents.

Women occupying non-traditional jobs may be particularly vulnerable to acts of physical violence, as they are in the minority and their presence may be resented or they may be perceived to be vulnerable. South Africa has adopted regulatory incentives to increase the presence of women in mines, a move designed to promote women's equality and ensure their access to better jobs. Yet many of the women who take up this challenge have been exposed to physical and sexual violence in the workplace. ${ }^{9}$

\section{(ii) Psychological Violence}

A significant body of literature has developed in recent years on workplace bullying, a phenomenon labelled differently in different jurisdictions. Bullying is the term used in Australia, the United Kingdom, the United States and other Anglo-Saxon jurisdictions; mobbing is a term more commonly used in Scandinavian and German-speaking countries; acoso or hostigamiento moral, in Spanish; harcèlement moral in France and Belgium; harcèlement psychologique in French-speaking Canada and psychological harassment is used in some Canadian legislation. All these terms designate similar phenomena. They are used in this article interchangeably. ${ }^{10}$

\footnotetext{
${ }^{8}$ Sylvain de Léséleuc, 'Criminal Victimization in the Workplace' (2007) Canadian Centre for Justice Statistics Profile Series 13

<https://www.publicsafety.gc.ca/lbrr/archives/cnmcs-plcng/cn000033259112-eng.pdf> accessed 28 May 2018.

${ }^{9}$ Lindiwe Zungu, 'Workplace Violence and Sexual Harassment Against Women Workers in the South African Mining Industry' (19-22 April 2016) Proceedings of the 10th International Conference on Workplace Bullying and Harassment, Auckland, New Zealand; Doret Botha, 'Women in Mining Still Exploited and Sexually Harassed' (2016) 14(1) South African Journal of Human Resource Management' 753.

${ }^{10} \mathrm{On}$ the origin of the different terms in different linguistic contexts see, Katherine Lippel, 'The Law of Workplace Bullying: An International Overview' (2010) 32 Comparative Labor Law \& Policy Journal 1.
} 
Leading scholars from organizational psychology, Ståle Einarsen and colleagues, define the concept as follows:

\begin{abstract}
Bullying at work is about repeated actions and practises that are directed against one or more workers; that are unwanted by the victim; that may be carried out deliberately or unconsciously, but clearly cause humiliation, offence, and distress; and that may interfere with work performance and/or cause an unpleasant working environment. ${ }^{11}$
\end{abstract}

They have also developed a precise measurement tool in the form of the Negative Act questionnaire. ${ }^{12}$ Their definition has been widely applied in management and organizational psychology research. ${ }^{13}$ Regulators, on the other hand, define the term differently in light of the regulatory contexts in which they are introducing the concept, so it is possible to find laws that include one single serious event under the definition of psychological harassment in jurisdictions in which other forms of violence, like intimidation, are not explicitly regulated. ${ }^{14}$

Verbal abuse, which does not necessarily fit the definition of bullying, harassment or mobbing, is included in many studies examining occupational violence in the workplace, ${ }^{15}$ and in guidance material produced by the ILO for the purpose of risk assessments in the workplace. ${ }^{16}$ Technology provides a vehicle to multiply opportunities for verbal abuse, and recently researchers and regulators have been turning their attention to technology-based violence, including cyber-bullying (cyber-intimidation) and other forms of violence facilitated by social

\footnotetext{
${ }^{11}$ Ståle Einarsen et al (eds) Bullying and Harassment in the Workplace: Development in Theory, Research and Practice (2 ${ }^{\text {nd }}$ ed, CRC Press, 2011) 9.

12 Dieter Zapf et al, 'Empirical Findings on Prevalence and Risk Groups of Bullying in the Workplace' in Ståle Einarsen et al (eds) Bullying and Harassment in the Workplace: Development in Theory, Research and Practice (2 ${ }^{\text {nd }}$ ed, CRC Press, 2011).

${ }^{13} \mathrm{Al}-\mathrm{Karim}$ Samnani and Parbudyal Singh, '20 Years of Workplace Bullying Research: A Review of the Antecedents and Consequences of Bullying in the Workplace' (2012) 17(6) Aggression and Violent Behaviour 581.

${ }^{14}$ For example s. 81.18 of the Québec Labour Standards Act, R.S.Q. c. N-1.1, defines psychological harassment to include some one-off events. The literature also discusses single events of bullying that can be experienced as a critical life event; see, Premilla D'Cruz et al, 'The Workplace Bullying-Organizational Change Interface: Emerging Challenges for Human Resource Management' (2014) 25(10) International Journal of Human Resource Management 1434.

${ }^{15}$ MB Fisekovic et al, 'Does Workplace Violence Exist in Primary Health Care? Evidence from Serbia' (2015) 25(4) European Journal of Public Health 693 applying the ILO, 'Workplace Violence in the Health Sector' (n 4).

${ }^{16}$ ILO et al, 'Code of Practice: Workplace Violence in Services Sectors and Measures to Combat this Phenomenon' (2003) <http://www.ilo.org/safework/info/standards-andinstruments/codes/WCMS_107705/lang--en/index.htm> accessed 28 February 2016.
} 
media and technology. ${ }^{17}$ Much of this work has looked at violence against women and girls, or cyber-bullying in schools, but little has focused on links between technology-based violence and work.

There are studies on workplace cyber-bullying looking at call centres in India, ${ }^{18}$ examining cyber-bullying across sectors in Sweden, ${ }^{19}$ and one from Australia which focused on male workers. ${ }^{20}$ Some of this literature looks at violence using traditional technology, the telephone. Call centre personnel in Germany have been found to be at risk for sexual harassment. ${ }^{21}$ French personnel working in customer support departments were also found to be targets of violence from customers, ${ }^{22}$ as were call-centre workers in China. ${ }^{23}$ Racial abuse is also a hazard of work in call centres. ${ }^{24}$ A study of call-centre work in Mexico, involving a majority of women workers, documented the prevalence of verbal abuse to which workers were exposed as well as mechanisms they developed to deal with violent interactions with clients. ${ }^{25}$

Regulation of cyber-bullying or cyber-based sexism is a challenge even in highly regulated societies, because of the ephemeral, non-physical nature of cyber posting. A recent Canadian judgment held that workplace human rights protections against discrimination on the basis of sex and marital status could not be applied to discriminatory speech expressed in a blog developed by a union in the context of collective

\footnotetext{
${ }^{17}$ See Women's Legal and Human Rights Bureau, 'From Impunity to Justice: Domestic Legal Remedies for Cases of Technology-Related Violence Against Women’ (2015) GenderIT.org <http://www.genderit.org/node/4268/> accessed 24 April 2018.

${ }^{18}$ Premilla D'Cruz and Ernesto Noronha, 'The Interface Between Technology and Customer Cyberbullying: Evidence from India' (2014) 24(3) Information and Organization 176.

${ }_{19}$ Rebecka Forssell, 'Exploring Cyberbullying and Face-to-Face Bullying in Working Life - Prevalence, Targets and Expressions' (2016) 58 Computers in Human Behavior 454 .

${ }^{20}$ Carmel Privitera and Marilyn Anne Campbell, 'Cyberbullying: The New Face of Workplace Bullying?' (2009) 12 CyberPsychology \& Behavior 395.

${ }^{21}$ Sabine Sczesny and Dagmar Stahlberg 'Sexual Harassment over the Telephone: Occupational Risk at Call Centres' (2000) 14 Work \& Stress 121.

${ }^{22}$ Anne Chevalier et al. 'Working Conditions and Psychosocial Risk Factors of Employees in French Electricity and Gas Company Customer Support Departments' (2011) 84 International Archives of Occupational and Environmental Health 7.

${ }^{23}$ Xiaoyan Li and Erhua Zhou, 'Influence of Customer Verbal Aggression on Employee Turnover Intention' (2013) 51 Management Decision 890.

${ }^{24}$ Vandana Nath 'Aesthetic and Emotional Labour through Stigma: National Identity Management and Racial Abuse in Offshored Indian Call Centres' (2011) 25 Work, Employment \& Society 709.

${ }^{25}$ Mireya Scarone and LeonorA. Cedillo, 'Psychosocial Risk Factors Among Telephone Service Workers: A Study of the Interaction Between Customer and Worker' (2007) 17 (12) New Solutions 137.
} 
bargaining. The Ontario Court of Appeal found that the speech in the blog had not been expressed 'in the workplace' ${ }^{26}$

\section{(iii) Sexual Violence}

Definitions and measures of sexual harassment vary between jurisdictions and cultures. ${ }^{27}$ The ILO Committee of Experts on the Application of Conventions and Recommendations defines sexual harassment as including the following elements:
(1) (quid pro quo) any physical, verbal or non-verbal conduct of a sexual nature and other conduct based on sex affecting the dignity of women and men which is unwelcome, unreasonable and offensive to the recipient; and a person's rejection of, or submission to, such conduct is used explicitly or implicitly as a basis for a decision which affects that person's job; or (2) (hostile work environment) conduct that creates an intimidating, hostile or humiliating working environment for the recipient. ${ }^{28}$

The European Directive 2006/54/EG (the recast directive) in article 2 defines both 'harassment' and 'sexual harassment'. ${ }^{29}$ Article 2(c) defines harassment: 'where unwanted conduct related to the sex of a person occurs with the purpose or effect of violating the dignity of a person, and of creating an intimidating, hostile, degrading, humiliating or offensive environment'. It also distinguishes it from 'sexual harassment': 'where

\footnotetext{
${ }^{26}$ Taylor-Baptiste v. Ontario Public Service Employees Union (2015) Ontario Court of Appeal 495 [4].

27 Chappell and Di Martino (n 2); Meg Bond et al, 'Expanding Our Understanding of the Psychosocial Work Environment: A Compendium of Measures of Discrimination, Harassment and Work-Family Issues' (NIOSH, 2007) <https://www.cdc.gov/niosh/docs/2008-104/pdfs/2008-104.pdf> accessed 24 April 2014; Yuki W.P. Huen, 'Workplace Sexual Harassment in Japan: A Review of Combating Measures Taken' (2011) 47 Asian Survey 811; Rashida Ather, 'Sexual Harassment at Workplace and Protective Measures for Women: National and International Perspectives' (2013) 3 (4) IUP Law Review 33; Lidia Casas Becerra, 'The Effectiveness of the Sexual Harassment Law in Chile: From Theory to Practice' (PhD thesis, University of Ottawa 2016).

${ }^{28}$ ILO, "Giving Globalization a Human Face' (2012)

<http://www.ilo.org/wcmsp5/groups/public/---ed_norm/--relconf/documents/meetingdocument/wcms_174846.pdf $>$ accessed 24 April 2018; See also ILO Committee of Experts on the Application of Conventions and Recommendations, 'General Observation Convention No 11' (2003) 463.

${ }^{29}$ Council Directive 2006/54/EC of 5 July 2006 on the implementation of the principle of equal opportunities and equal treatment of men and women in matters of employment and occupation (recast) [2006] OJ L204/23.
} 
any form of unwanted verbal, non-verbal or physical conduct of a sexual nature occurs, with the purpose or effect of violating the dignity of a person, in particular when creating an intimidating, hostile, degrading, humiliating or offensive environment.' The Directive includes both harassment and sexual harassment in the definition of discrimination, which it prohibits. The Directive thus addresses both unwanted sexual attention in the workplace and the poisoned work environment. It is useful to note that some surveys on working conditions in Europe ${ }^{30}$ and Québec ${ }^{31}$ have used questions on unwanted sexual attention as a proxy for sexual harassment, without asking about the poisoned work environment, which may in part explain low levels of reporting of sexual harassment in some surveys.

Literature from the United States specifies that the concept of sexual harassment can also include 'quid pro quo behaviors where the unwelcome behavior becomes a term or condition of employment or advancement.' 32

Sexual harassment is under-reported, ${ }^{33}$ and may overlap with other forms of violence ${ }^{34}$ or be subsumed into the broader concept of psychological harassment, particularly if targets are stigmatized when complaining of sexual or gender based harassment. ${ }^{35}$ The vast majority of targets of sexual harassment are women and the vast majority of perpetrators are men. However, there are cases of sexual harassment

\footnotetext{
${ }^{30}$ Eurofound, 'Physical and Psychological Violence at the Workplace' (Publications Office of the EU, 2013) <http://www.eurofound.europa.eu/publications/foundationfindings/2014/working-conditions/foundation-findings-physical-and-psychologicalviolence-at-the-workplace $>$ accessed 24 April 2018. The report at page 8 notes that unwanted sexual attention was used as a proxy for sexual harassment until the 2010 survey.

${ }^{31}$ Katherine Lippel et al, 'Violence au travail: Harcèlement psychologique, harcèlement sexuel et violence physique' in M. Vézina et al, Enquête québécoise sur des conditions de travail, d'emploi, et de santé et de sécurité du travail (EQCOTESST, 2011) 325 <http://www.irsst.qc.ca/media/documents/PubIRSST/R-691.pdf> accessed 18 June 2018.

${ }^{32}$ Kimberly T. Schneider et al 'Sexual Harassment Research in the United States' in Ståle Einarsen et al (eds) Bullying and Harassment in the Workplace: Development in Theory, Research and Practice (2nd ed, CRC Press, 2011).

${ }^{33}$ Kristin Van De Griend and DeAnne Hilfinger Messias, 'Expanding the

Conceptualization of Workplace Violence: Implications for Research, Policy, and Practice' (2014) 71 Sex Roles 33.

${ }^{34}$ Eurofound (n 30).

${ }^{35}$ Rachel Cox, 'From Sexual to Psychological Harassment: One Step Forward, Twenty-Five Years Back for Women's Equality at Work?' in Shelagh Day, Lucie Lamarche and Ken Norman (eds) 14 Arguments in Favour of Human Rights Institutions (Irwin Law, 2014).
} 
where the targets are men, and the perpetrators may be either men or women. ${ }^{36}$

Precarious employment, notably temporary contracts, has been found to increase the risk of exposure to sexual harassment in an Australian study, ${ }^{37}$, and again in a Québec study, ${ }^{38}$ although studies in both jurisdictions also found that the precariously employed were less likely to be exposed to psychological harassment. ${ }^{39}$ This suggests that the phenomena are quite differently motivated, with sexual harassment being easier to perpetrate when targets are precariously employed, while psychological harassment being more likely to target workers on longterm contracts, perhaps because it is sometimes used strategically to exclude individuals from the workplace who are not perceived to be desirable by management or colleagues. Workers on temporary contracts may be excluded from the workplace simply by not renewing their contract, a strategy unavailable to management when the worker has better job security.

Women working in non-traditional jobs are particularly vulnerable to sexual harassment. Despite South Africa's efforts to promote women's participation in the mining industry, the prevalence of sexual harassment and sexual violence have led to calls for improved practices and leadership to ensure that sexual harassment policies are applied and that effective support systems for women put in place. ${ }^{40}$

\section{(iv) Discriminatory Harassment}

Discriminatory harassment, including gender based harassment, ${ }^{41}$ has received less attention in the literature than sexual harassment. It has been prohibited in international instruments and national legislation in

\footnotetext{
${ }^{36}$ Paula McDonald and Sara Charlesworth, 'Workplace Sexual Harassment at the Margins' (2016) 30 Work, Employment \& Society 118.

${ }^{37}$ Anthony D. LaMontagne et al, 'Unwanted Sexual Advances at Work: Variations by Employment Arrangement in a Sample of Working Australians' (2009) 33 Australian and New Zealand Journal of Public Health 173.

${ }^{38}$ Katherine Lippel et al, 'Workplace Psychological Harassment: Gendered Exposures and Implications for Policy' (2016) 46 (1) International Journal of Law and Psychiatry 74.

39 ibid; Dominic Keuskamp et al, 'Workplace Bullying a Risk for Permanent Employees' (2012) 36 Australian and New Zealand Journal of Public Health 116.

${ }^{40}$ Botha (n 9).

${ }^{41}$ Gender-based harassment is discriminatory harassment motivated by the gender of the target, and does not intrinsically involve sexual innuendo. Gender-based harassment, but not sexual-advance harassment, was found to be related to the under-representation of women in male-dominated workplaces, although men in female-dominated workplaces were not more exposed to either form of harassment, see Dana Kabat-Farr and Lilia M. Cortina, 'Sex-Based Harassment in Employment: New Insights into Gender and Context' (2014) 38 Law and Human Behavior 58.
} 
North America, Australia, and Europe for a number of years. The legislation governing discriminatory harassment usually requires that the harassment be shown to be related to a prohibited ground of discrimination and the categories protected by national legislation vary considerably. Harassment against racialized minorities is understood to be prohibited in most human rights instruments, but the prohibition against harassment on the basis of age or sexual orientation is less universal. Even though harassment on the basis of ethnicity or race is prohibited in many countries, effectiveness of those protections is rarely studied. Those studies that do exist show that racialized minorities are more often exposed to harassment and discriminatory treatment. ${ }^{42}$ Bullying and harassment of workers with disabilities has not been studied extensively. ${ }^{43}$

There is an emerging body of literature on harassment based on sexual orientation and gender identities, ${ }^{44}$ notably in Australia, ${ }^{45}$ where discrimination on the basis of sexual orientation is prohibited. In the United States, where sexual orientation is not included in Title VII protections, 46 researchers have documented adverse effects of discrimination and harassment related to sexual orientation and its effects on health, and have suggested regulatory measures to improve protection. ${ }^{47}$

\footnotetext{
${ }^{42}$ In Canada, see Stephanie Premji and Wayne Lewchuk, 'Racialized and Gendered Disparities in Occupational Exposures among Chinese and White Workers in Toronto' (2013) 19 (5) Ethnicity \& Health 512; in the US, see Pat Chew, 'Freeing Racial Harassment from the Sexual Harassment Model' (2007) University of Pittsburgh School of Law Working Paper Series <http://law.bepress.com/pittlwps/papers/art54> accessed 24 April 2018.

43 In the UK, see Ralph Fevre et al, 'The Ill-Treatment of Employees with Disabilities in British Workplaces' (2013) 27 Work, Employment and Society 288.

${ }^{44}$ On work-related discrimination toward transgender individuals in the US, see Varunee Sangganjanavanich and Javier Cavazos, 'Workplace Aggression: Toward Social Justice and Advocacy in Counseling for Transgender Individuals' (2010) 4 Journal of LGBT Issues in Counseling 187.

45 Tania Ferfolja, 'Lesbian Teachers, Harassment and the Workplace' (2010) 26 Teaching and Teacher Education 408.

${ }^{46}$ Title VII of Civil Rights Act of 1964, Pub. L. No. 88-352, 78 Stat. 241 (US) as amended, prohibits discrimination in employment based on 'race, color, religion, sex (including pregnancy, childbirth and related medical conditions) and national origin'. The Americans With Disabilities Act of 1990, Pub. L. No. 101-336, 104 Stat. 328 (1990) (US) prohibits discrimination on the basis of disability. See US Equal Employment Opportunity Commission, <https://www.eeoc.gov/laws/statutes/titlevii.cfm> accessed on 10 July 2016.

47 Veronica Rabelo and Lilia Cortina, 'Two Sides of the Same Coin: Gender Harassment and Heterosexist Harassment in LGBQ Work Lives' (2014) 38 Law and Human Behavior 378.
} 


\section{(v) Intimate Partner Violence and Work}

Women are disproportionately targets of intimate partner violence, discussed here insofar as it relates to workplaces and work: intimate partner violence that occurs in the workplace and intimate partner violence that affects the worker's ability to do her work or keep her job. ${ }^{48}$ Other issues in the literature include studies of the spill-over effect of work that can increase the risk of a worker becoming a perpetrator of domestic violence ${ }^{49}$ and studies that call for workplaces to manage their employees who are perpetrators of domestic violence outside the workplace. ${ }^{50}$

In the United States, intimate partner violence is considered to be a public health issue, and between 2003 and 2008, one third of workplace homicides among US women were perpetrated by a personal relation, the majority attributed to an intimate partner. ${ }^{51}$ Yet in the United Kingdom, the Health and Safety Executive uses the Crime Survey for England and Wales to report on violence at work but excludes domestic violence from the purview of the report because 'these cases are likely to be very different in nature from other experiences of violence at work. ${ }^{5} 2$

Domestic violence, regardless of where it occurs, can have a negative impact on the target's ability to get to work, to stay at work or to work well, and there are studies from New Zealand, ${ }^{53}$ Canada, ${ }^{54}$ Australia, ${ }^{55}$

\footnotetext{
${ }^{48}$ A recent survey found that the consequences of domestic violence impact victims' work lives. See C. Nadine Wathen et al, 'The Impact of Domestic Violence in the Workplace: Results from a Pan-Canadian Survey' (2015) 57 JOEM e65.

${ }^{49}$ Scott A. Melzer, 'Gender, Work, and Intimate Violence: Men's Occupational Violence Spillover and Compensatory Violence' (2002) 64 Journal of Marriage and Family 820.

${ }^{50}$ Katherine Martinez, 'Not Just Domestic Violence: The Role of the Workplace in Mitigating Abusers' (2015) 15 University of Maryland Law Journal of Race, Religion, Gender \& Class 15.

${ }^{51}$ Hope P. Tiesman et al, 'Workplace Homicides among U.S. Women: The Role of Intimate Partner Violence' (2012) 22 Ann Epidemiol 227. See US Bureau of Labor (n 5): 'assailants in workplace homicides differed greatly depending on the gender of the decedent. Approximately 43 percent of female decedents were fatally assaulted by a relative or domestic partner; the corresponding figure for male decedents was 2 percent'.

52 Paul Buckley, 'Violence at Work 2016/2017' (2018) Health and Safety Executive (UK) <http://www.hse.gov.uk/statistics/causinj/violence/work-related-violence-report2018.pdf> accessed 21 May 2018.

${ }^{53}$ Margaret M. Rayner-Thomas, 'The Impacts of Domestic Violence on Workers and the Workplace' (Master of Public Health Thesis, University of Auckland 2013).

${ }^{54}$ Wathen et al (n 48).

${ }^{55}$ Male Champions of Change, 'Playing Our Part: Workplace Responses to Domestic and Family Violence' (2015) < http://malechampionsofchange.com/wpcontent/uploads/2015/11/Playing-Our-Part-Male-Champions-of-Change-Letter.pdf> accessed 6 February 2016.
} 
and the United States 56 which document ways in which targets' performance at work can be negatively affected by intimate partner violence outside of work and ways in which they can be supported by workplaces.

\section{B. Applying a Gender Lens to the Prevention of Workplace Violence}

While it is not possible to provide an exhaustive overview of prevention strategies for the different forms of occupational violence and violence against women in the workplace and during the commute between home and work, here we will illustrate the types of interventions that could be or have been considered as effective in the prevention of violence. These types of interventions are primarily for the purpose of circumscribing the types of activities which need to be promoted by regulatory frameworks to be discussed in the next section. The purpose is not to determine whether criminal law, for example, is more effective than economic sanction. Rather, the hope is to illustrate, in light of the literature, examples of intervention strategies which could feasibly be implemented in workplaces and in communities if the proper (regulatory) incentives were in place.

(i) Identifying Determinants of Violence Targeting Workers

Occupational violence in its many forms is often associated with organizational factors that provide fertile ground for both internal and external violence. 'Systemic violence' refers to 'violence yielded by the working organization' and 'means that the structure of the organization can have features which make workers liable to violence. For example, maximizing the economic outcome of the organisation or simple indifference may lead to defective protection of the worker' ${ }^{57}$ The term 'structural violence' has been used

to identify the heavy workloads, low levels of decision-making autonomy, low status, rigid work routines and insufficient relational care as forms of violence. Not only are these poor working conditions

\footnotetext{
${ }^{56}$ Jessie B. Brown, 'Costs of Domestic Violence in the Employment Arena: A Call for Legal Reform and Community-Based Education Initiatives' (2008) 16 Virginia Journal of Social Policy \& the Law 1; Julie Goldscheid, 'Gender Violence and Work: Reckoning with the Boundaries of Sex Discrimination Law' (2009) 18 Columbia Journal of Gender and Law 61.

${ }^{57}$ Heiskanen (n 6) 24.
} 
experienced as sources of suffering but they prevent care workers from providing the kind of care they know they are capable of. ${ }^{58}$

The same authors link the streamlined treatment of residents in the context of restructuring of the health care sector with an increase in violence against care workers. For example the use of cost-saving strategies based on rationing of diapers in a residential care facility was found to be a trigger of violent incidents by residents against staff, who were instructed to not change a diaper of an incontinent elder unless a blue line appeared on the diaper, showing it to be sufficiently saturated to justify the cost of changing the diaper. ${ }^{59}$

Exposure to a broad range of psychosocial risk factors, including organisational factors, has been found to be associated with bullying and harassment. Job strain (high work demands with low decision latitude), job insecurity ${ }^{60}$ and a poor psychosocial safety climate ${ }^{61}$ are known determinants of workplace bullying, findings confirmed in reviews of the international scientific literature ${ }^{62}$ and in studies from Australia, ${ }^{63}$ Belgium, ${ }^{64}$ and Québec. ${ }^{65}$ The literature also discusses other forms of workplace aggression, including incivility. ${ }^{66}$ Some of these categories can be considered as psychosocial risk factors that are precursors to other forms of occupational violence.

\footnotetext{
58 Albert Banerjee et al, 'Structural Violence in Long-Term, Residential Care for Older People: Comparing Canada and Scandinavia' (2012) 74 Social Science \& Medicine 390, 391.

${ }_{59}$ Pat Armstrong et al, They Deserve Better: The Long-Term Care Experience in Canada and Scandinavia, (Canadian Centre for Policy Alternatives, 2009).

${ }^{60}$ Denise Salin and Helge Hoel, 'Organisational Causes of Workplace Bullying', in Ståle Einarsen et al (eds) Bullying and Harassment in the Workplace: Development in Theory, Research and Practice (2nd ed, CRC Press, 2011) 227. For explanatory pathways see Michelle R. Tuckey et al, 'Workplace Bullying: The Role of Psychosocial Work Environment Factors' (2009) 16(3) International Journal of Stress Management 215. For an overview see ILO, 'Psychosocial Risks, Stress and Violence in the World of Work' (2016) 8 (1-2) International Journal of Labour Research 1.

${ }^{61}$ Tessa S. Bailey et al, 'A National Standard for Psychosocial Safety Climate (PSC): PSC 41 as the Benchmark for Low Risk of Job Strain and Depressive Symptoms' (2015) 20(1) Journal of Occupational Health Psychology 15. A healthy psychosocial safety climate requires management commitment to psychological health and safety; see Rachel Potter et al, 'Bullying $\&$ Harassment in Australian Workplaces' (Safe Work Australia, 2016).

62 Salin and Hoel (n 60).

63 Tuckey et al (n 60) and Potter et al (n 61).

${ }^{64}$ Elfi Baillien and Hans De Witte, 'Why is Organizational Change Related to Workplace Bullying? Role Conflict and Job Insecurity as Mediators' (2009) 30 (3) Economic and Industrial Democracy 348.

${ }^{65}$ Lippel et al, 'Workplace Psychological Harassment' (n 38).

${ }^{66}$ See Brad Estes and Jia Wang, 'Integrative Literature Review: Workplace Incivility: Impacts on Individual and Organizational Performance' (2008) 7 Human Resource Development 218.
} 
A key factor in reducing exposure to psychological violence, including bullying and harassment, as well as sexual harassment is to find ways to make these behaviours unacceptable in the workplace. This is achieved not just by posting policies declaring them to be unacceptable but by changing the workplace culture so that there is a shared perception that such behaviour, that may have been prevalent and accepted years ago, is no longer tolerated either by management or by workers and their unions. The active participation of unions in educating the workforce with regard to sexual harassment ${ }^{67}$ or bullying ${ }^{68}$ can be far more successful in reducing these behaviours than top down orders from management or zero tolerance policies that raise the stakes for perpetrators, possibly exacerbating ill-feeling in the workplace.

A study of occupational hazards of call-centre work in Mexico discussed ways in which workers and their union can protect the health of workers exposed to violence, and concluded that participatory research with the workers and academics had empowered the workers to identify sources of distress and to act upon their knowledge. ${ }^{69}$

Far less literature addresses the prevention of violence perpetrated while workers commute to and from work. In part, this is explained by the fact that in many countries, including those in North America, injury incurred while travelling to and from work is not compensable under workers' compensation law. Often prevention is driven by costs to the workplace, although some regulators have nonetheless provided guidance material to encourage employers to consider hazardous commutes when organizing the design of parking lots and scheduling shifts. ${ }^{70}$ Vulnerability of women to violent attacks occurring while travelling to and from work has been acknowledged as an obstacle to integration of women in the mining workforce in South Africa, for example, where, despite incentives for mining companies to hire more women, the lack of accommodation for women at the mines, and the shift

67 Trade Union Congress, 'Still Just a Bit of Banter: Sexual Harassment in the Workplace in 2016' (2016)

<https://www.tuc.org.uk/sites/default/files/SexualHarassmentreport2016.pdf> accessed on 24 April 2018.

${ }^{68}$ Rachel Cox, 'Québec Unions' Role with Respect to Complaints of Psychological Harassment in the Workplace: The Peril and Promise of Implementing Individual Rights Through Collective Labour Relations' (2015) 13 (2) Policy and Practice in Health and Safety 69.

${ }^{69}$ Scarone and Cedillo (n 25).

${ }^{70}$ Worksafe BC, 'Take Care: How to Develop and Implement a Workplace Violence Prevention Program'

<http://www.worksafebc.com/publications/health_and_safety/by_topic/assets/pdf/tak e_care.pdf $>$ accessed 24 April 2018. 
design, require they travel long hours to get to and from work. ${ }^{71}$ The International Monetary Fund's report on integrating women into the Moroccan workforce has underlined the importance of improving public transport to facilitate and make more secure women's journeys to and from work. ${ }^{72}$

Intimate partner violence relates to work either because the manifestations of violence occur at work, or because the workplace is called upon to accommodate the needs of workers who are targets of intimate partner violence outside the workplace. As we have seen above, there are ongoing discussions regarding regulatory protections in labour law to ensure targets' safety, on the one hand, and to require they be supported to ensure their ongoing employment, on the other.

\section{(ii) Understanding the Gendered Nature of Workplace Violence}

Unsurprisingly, women are more often the targets of sexual violence and domestic violence, but it is equally important to address work related physical violence, prevalent in certain sectors where women are in the majority, such as the health care sector. This is a priority issue in most countries, to the point where the ILO, in collaboration with the International Council of Nurses, the WHO and the Public Services International, developed a questionnaire designed to measure workplace violence in the health sector in different countries, and dozens of studies have focused on the risks of physical violence in the health sector in every continent. ${ }^{73}$ Studies have also found that workers in the field of education are disproportionately targets of physical violence and threats of violence, ${ }^{74}$ and again, women make up the majority of the workforce in education in many countries.

When work involves care giving (healthcare sector) and child rearing (education) violent acts perpetrated by patients and students have been found to be perceived as normal by supervisors and workers in these sectors. As a result, many incidents go unreported, and no prevention efforts are put into place because the problem is largely invisible. Putting an end to the normalization of physical violence would be a significant step towards reducing exposure of workers to acts of physical violence in

\footnotetext{
${ }^{71}$ Asand P. Benya, 'Women in Mining: A Challenge to Occupational Culture in Mines' (Masters of Arts (Industrial Sociology) Thesis, University of the Witwatersrand 2009).

${ }^{72}$ International Monetary Fund, 'Morocco: Reducing Gender Inequality Can Boost Growth' <https://www.imf.org/en/News/Articles/2017/03/01/NA0301 17-MoroccoReducing-Gender-Inequality-Can-Boost-Growth> accessed on 24 June 2017.

${ }^{73}$ See Lippel, 'Addressing Occupational Violence' (n 1) 19.

74 ibid 20.
} 
these sectors. ${ }^{75}$ Violence against domestic workers, particularly those living in the employer's home, has been especially hard to tackle as workers are alone with the perpetrators and often dependent on them for everything from their livelihood to their ability to remain in the country. This explains why violence in domestic work was one of the first categories to be addressed by an ILO convention. ${ }^{76}$

Women have been found to be disproportionately targets of psychological violence in some studies but not in others. A Québec study found that socio-economic status within the workplace, related to position in the corporate hierarchy, education and salary, was protective for men: the higher their status, the less likely they were to be targets of psychological harassment, yet the same was not true for professional or managerial women, who were not protected by their status. ${ }^{77}$ This example illustrates the importance of stratified analysis in studies of occupational violence. If all cases were analyzed together, it would have given the impression that the position in the hierarchy was protective for all workers. Only when you analyse data separately, by sex, can you see that specific types of violence play out differently for men and women.

Gender is not always a determinant in the exposure to violence. Other studies on bullying have not found gender differences, and it is likely that national contexts play a role in the gender dimensions of occupational violence, if we consider forms of violence that are potentially gender neutral, as opposed to sexual violence or intimate partner violence which is a priori gendered in its production. A systematic review of the literature on verbal violence, applying a gender lens, found that most studies did not conclude there were gender differences, although a few found that men were more exposed than women. ${ }^{78}$

75 ibid 25.

76 ibid 20. See C189-Domestic Workers Convention, 2011 (No. 189).

77 Lippel et al, 'Workplace Psychological Harassment' (n 38). See also Denise Salin, 'The Significance of Gender for Third Parties' Perceptions of Negative Interpersonal Behaviour: Labelling and Explaining Negative Acts' (2011) 18 Gender, Work \& Organization 571.

${ }^{78}$ Stephane Guay et al, 'Verbal Violence in the Workplace According to Victims' Sex-a Systematic Review of the Literature' (2014) 19 Aggression and Violent Behavior 572. 


\section{Regulatory Protection from Workplace Violence and its Consequences}

\section{A. International and Regional Regulatory Approaches}

There are no ILO conventions dedicated to occupational violence although a number of ILO instruments refer either directly or indirectly to certain manifestations of violence. For example, conventions looking at specific sectors such as domestic work ${ }^{79}$ or maritime labour ${ }^{80}$ contain language addressing some forms of occupational violence. Several UN human rights treaties and conventions contain provisions targeting specific categories of violence, such as sexual harassment, without focussing on the workplace. The UN Convention on the Protection of the Rights of all Migrant Workers and Members of their Families ${ }^{81}$ does focus on abuse and violence against migrant workers, although not specifically in the context of the workplace, but clearly it would apply to workplaces as well as the broader communities. The UN Convention on the Rights of Persons with Disabilities contains specific provisions on violence and abuse. ${ }^{82}$ The UN Convention on the Elimination of All Forms of Discrimination Against Women (CEDAW) has been interpreted to encompass violence. CEDAW 'provides protections against gender based violence, including sexual assault and harassment: the treaty's definition of discrimination has been interpreted to include these abuses. [...] The General Recommendation also states clearly that sexual harassment in the workplace is a form of violence against women.' 83

There are also regional instruments, including the European Social Charter, 84 the European Council Directive 2000/78/EC, 85 the European Council Directive 2006/54/EG (The Recast Directive), ${ }^{86}$ and

\footnotetext{
${ }^{79}$ Domestic Workers Convention (No. 76).

80 'Amendments of 2016 to the Code of Maritime Labour Convention, 2006' (2016) ILC. 105/PR/3-1A.

${ }^{81}$ Article 16(2) (adopted 18 December 1990, entered into force 1 July 2003) A/RES/45/158.

${ }^{82}$ Article 1(b) (harassment), Article 16 (violence and abuse), Article 27 (work and employment) (adopted 13 December 2006, entry into force 3 May 2008) A/RES/61 / 106 ${ }^{83}$ (adopted 18 December 1979, entry into force 3 September 1981) 1249 UNTS 3; Margaret Satterthwaite, 'Crossing Borders, Claiming Rights: Using Human Rights Law to Empower Women Migrant Workers' (2005) 8(1) Yale Human Rights \& Development Law Journal 1,19, 48.

${ }^{84}$ Council of Europe, European Social Charter (Revised), 3 May 1996, ETS 163.

${ }^{85}$ Council Directive 2000/78/EC of 27 November 2000 establishing a general framework for equal treatment in employment and occupation [2000] OJL 303.

86 The Recast Directive (n 29).
} 
the European Council Directive 1989/89/391 on occupational health and safety. ${ }^{87}$ These instruments do oblige states to report on their progress in addressing sexual harassment and bullying, to provide powers to inspectorates and remedies for targets of certain categories of occupational violence. ${ }^{88}$ In Europe, there is also the Istanbul Convention on Violence against Women that contains provisions on sexual harassment and domestic violence, but that does not explicitly focus on work or violence in the workplace. ${ }^{89}$ In Africa, there is the Maputo Protocol ${ }^{90}$ on women that explicitly addresses sexual harassment at work, and sexual harassment in the workplace is also explicitly mentioned in the Inter-American Convention on the Prevention, Punishment, and Eradication of Violence against Women. ${ }^{91}$ In Asia, there is the Declaration on the Elimination of Violence Against Women and Elimination of Violence Against Children in ASEAN, ${ }^{92}$ but there is no specific focus on work.

There is thus a patchwork quilt of provisions addressing some forms of violence against some categories of workers, of both sexes in some cases while applicable specifically to women in others, but to this day there is no international convention that addresses all forms of occupational violence and that seeks to ensure protection for all workers.

\section{B. Selected National Approaches}

There are a broad range of categories of national legislation that are either designed to address occupational violence or that may be used by targets who seek protection or who seek compensation for injury suffered at the hands of perpetrators of violence. Some are reserved for specific categories of violence while others, such as workers' compensation, can address all forms of workplace injury including injury attributable to

\footnotetext{
${ }^{87}$ Council Directive 89/391/EEC of 12 June 1989 on the introduction of measures to encourage improvements in the safety and health of workers at work [1989] OJ L183.

${ }^{88}$ See Lippel, 'Addressing Occupational Violence' (n 1) 33-9.

${ }^{89}$ Council of Europe Convention on Preventing and Combating Violence Against Women and Domestic Violence (Council of Europe Treaty Series-No. 210).

${ }^{90}$ Protocol to the African Charter on Human and Peoples' Rights on the Rights of Women in Africa, (Maputo Protocol) (adopted 11 July 2003, entry into force 25

November 2005) CAB/LEG/66.6, art 1(j), 3(4) and 13(c).

${ }^{91}$ Organization of American States, Inter-American Convention on the Prevention, Punishment and Eradication of Violence against Women (Convention of Belém do Pará, 1994) art 2 <https://www.oas.org/en/mesecvi/docs/BelemDoPara-ENGLISH.pdf> accessed 24 April 2018.

92 Declaration on the Elimination of Violence Against Women and Elimination of Violence Against Children in ASEAN,

<http://www.ohchr.org/Documents/Issues/Women/WG/ASEANdeclarationVaW_vio lenceagainstchildren.pdf> accessed 24 April 2018.
} 
workplace physical and psychological violence. Not many regulatory approaches have been studied to determine their effectiveness, and what is effective in one jurisdiction may fail to be useful in another depending on the social climate, the nature of regulatory inspection, and the degree to which workers and employers are conscious of the specific type of violence to be eradicated.

The nature of the most effective regulatory approaches may depend on national context. For example, constitutional protections of workers guaranteeing decent working conditions and occupational health and safety protections are the recourse of choice for targets of bullying in Brazil, ${ }^{93}$ Chile $^{94}$ and Columbia ${ }^{95}$ because in these countries the violation of a constitutional right provides access to a simple, affordable remedy the tutela. While several countries now have explicit legislation against bullying and harassment, the formal labour legislation only applies to employees, a situation ill-suited to economies such as that of Colombia, where the majority of workers are in the informal sector. ${ }^{96}$

In contrast, explicit legislation on bullying can be very effective as a pedagogical tool in jurisdictions with a high rate of unionization and a largely formal workforce, particularly if the unions are called upon to provide representation to targets of bullying, not just to members who have been disciplined for acts of bullying. In Québec, for the $40 \%$ of the workforce that is unionized, the anti-bullying legislation requires that recourse be exercised through the union, and representation is provided by the state to non-unionized targets having a prima facie case. ${ }^{97}$ This legislation, in force since 2004, has attracted a great deal of attention as well as a great deal of criticism as it places an onerous burden on unions to defend targets, while the Labour Code requires the union to defend members who have been sanctioned by the employer. In many cases the union must therefore defend both the target and the perpetrator, which creates conundrums and costs. However, one major effect of this regulatory approach is to have provided a compelling incentive to unions to educate their members regarding psychological harassment and sexual

\footnotetext{
${ }^{93}$ Julia Gitahy da Paixao, 'El Acoso Laboral en el Ordenamiento Juridico del Brasil: Marco Legal Y Fallos Recientes' (2012) 7 Revista Estudios Laborales 123.

${ }^{94}$ Diego Lopez Fernandez, 'Legal Protection for Victims of Workplace Harassment in Chile' (2010) 32 Comparative Labor Law \& Policy Journal 91; subsequent Chilean legislation introduced a specific recourse for targets of bullying.

${ }^{95}$ Laura Porras Santanilla, 'La Ley de acoso laboral en Colombia ¿facilitó o por el contrario dificultó la protección efectiva de las personas afectadas?' (2012) 7 Revista Estudios Laborales 141.

96 ibid.

${ }^{97}$ See Cox 'Quebec Unions' (n 68) and Rachel Cox, 'Psychological Harassment Legislation in Québec: The First Five Years' (2010) 32 Comparative Labor Law \& Policy Journal 55.
} 
harassment, understood to be included within the purview of the antiharassment legislation. Because all targets with a prima facie case are supposed to have representation, and because the employer is responsible for eliminating psychological harassment in the workplace, both employers and unions have a vested interest in ensuring prevention at the source. When this works well, which is often when relations between unions and management are constructive, the workplace actors reduce the risk of exposure to psychological harassment by intervening before situations get out of hand. However, when industrial relations are poor, the target of harassment becomes embroiled in a complex, drawn out, litigious process that can exacerbate any health problems that might result from exposure to psychological violence..$^{98}$

Aside from legislation targeting specific forms of violence, such as bullying and sexual harassment, a broad range of regulatory frameworks are applied to either prevent or punish workplace violence. These include general legislation such as criminal and civil law, human rights provisions and labour law (most notably non-discrimination law), and legislation governing occupational health and safety and workers' compensation. ${ }^{99}$ Increasing costs of workers' compensation and sickness insurance associated with occupational violence have led in recent years to regulatory interventions to promote better risk assessments in workplaces with regard to violence. ${ }^{100}$ In Belgium, where anti-bullying provisions were enacted in the Labour Code in 2002, changes were introduced in 2014 to require that psychosocial risk factors be addressed by employers, regardless of incidents of harassment or violence. ${ }^{101}$ The Occupational Safety and Health Administration (OSHA) of the US Department of Labor recently published a request for information, stating that 'OSHA is considering whether a standard is needed to protect healthcare and social assistance employees from workplace violence'. ${ }^{102}$ Although this is not an exhaustive overview of recent developments, it shows that

\footnotetext{
${ }^{98}$ Cox 'Quebec Unions' (n 68). The same conclusions apply to prevention of psychosocial hazards more generally; see David Walters, 'Worker Representation and Psycho-Social Risks: A Problematic Relationship?' (2011) 49 Safety Science 599.

99 See Lippel, 'Addressing Occupational Violence' (n 1) 39-49.

${ }^{100}$ In 2016, Norway amended the regulation on the conduct of work to impose stricter obligations on companies to assess the risk of threats and violence against their employees and to train their employees on how to prevent and deal with threats and violence; see Eurofound, 'Norway: Latest Working Life Developments - Q4 2016' (2017) <https://www.eurofound.europa.eu/observatories/eurwork/articles/norway-latestworking-life-developments-q4-2016> accessed 2 March 2017.

${ }^{101}$ Federal Public Service Employment, Labour and Social Dialogue, 'Nouvelle législation relative aux risques psychosociaux au travail à partir du 1 er septembre 2014 . <http://www.emploi.belgique.be/defaultNews.aspx?id=41483> accessed 24 April 2018.

${ }^{102}$ RIN 1218-AD 08, 'Prevention of Workplace Violence in Healthcare and Social Assistance' (7 December 2016) 81(235) Federal Register 88147.
} 
occupational violence is high on the agenda of various countries, albeit with different priorities and different approaches to the issue.

\section{Applying a Gender Lens to the Regulation of Workplace Violence}

Several authors have noted that remedies sought by women alleging workplace violence perpetrated by colleagues or subordinates appear to be compromised by the natural identification of traditional workplace actors and regulators with the target of sanctions imposed by the employer. For example, Lidia Casas Becerra, in her doctoral thesis on uptake of sexual harassment legislative protections in Chile, describes obstacles to effective implementation of sexual harassment legislation in the workplace. ${ }^{103}$ First, women workers themselves were hesitant to label unwanted sexual attention as sexual harassment, and were thus unlikely to complain or to draw the attention of labour inspectors. Workplaces in Chile are required to address sexual harassment in internal regulations, but many participants in her study were unaware of the existence of such rules. Finally, when workers did try to exercise their rights, decision makers were often hesitant to punish perpetrators of sexual harassment as the labour courts had a long tradition of protecting job security. In the majority of cases studied, the perpetrator was the plaintiff contesting disciplinary measures, and the success rates of perpetrators contesting the sanction imposed by the employer was actually higher than the success rate of targets of sexual harassment who had filed complaints. Her results suggest that addressing external violence is more easily the subject of a workplace consensus than addressing internal violence where supervisors and colleagues are the perpetrators.

Sometimes the explicit regulatory interventions distinguish between internal and external violence in a way that may appear to trivialize internal violence as compared to that involving perpetrators from outside the workplace. For example, an early occupational health and safety regulation adopted in British Columbia and is still in force, prohibits violence from all sources but labels all forms of violence by internal perpetrators, including physical or sexual violence, as improper behaviour' while reserving the term 'violence' for 'attempted or actual exercise of physical force by a person other than a worker so as to cause injury to a worker'. ${ }^{104}$ This regulatory approach sends the message that internal violence is somehow less important than external violence, particularly given that obligations placed on employers are less stringent with regard to 'improper behaviour'. Yet nothing in the literature

103 Casas Becerra (n 27).

104 Occupational Health and Safety Regulation (BC Reg 296/97) ss 4.24-2.27. 
suggests that negative health effects are greater when the perpetrator comes from outside the organization. On the contrary, studies have found few differences in health consequences but they have found that internal violence has a greater impact on targets' well-being and ability to remain in the job. ${ }^{105}$

A judgment from the Ontario Court of Appeal failed to overturn a lower court judgment that weighed competing human rights values in this context. The facts illustrated a conflict between the freedom of expression of the union president, who criticized a manager in terms that crassly focussed on her personal life, and the protection of workers from sexism. All decisions in this case found in favour of the union president's free speech, thereby trivializing the sexist nature of the speech in a way that suggested it was reasonable to conclude that the complainant's equality rights had not been violated. In the words of the Divisional Court, as cited by the Court of Appeal, 'her concern and upset would have been largely the same whether the point about her relationship with Mr. [...] was made using sexist language or not.'106 The Court of Appeal approved the reasoning of the Human Rights Tribunal when it went on to specify that 'hate speech' or 'violent expression' were not protected under the right to freedom of expression in The Canadian Charter of Rights and Freedoms but that the blog postings, judged to be protected speech, 'were not hate speech. They contained rude, distasteful and sexist remarks which even [the author] acknowledged upon reflection appeared to him to have been "written by an asshole". ${ }^{107}$

\section{Conclusion}

Occupational violence affects both men and women, although it is clear that they may be targeted differently, for different reasons and in different ways. All workers who are victims of violence may suffer serious health consequences to both their physical and mental health. Rather than focussing only on the promotion of protections for women in the workplace, it seems that the more effective strategy to ensure uptake of regulatory protections by employers of workers, their representatives and society as a whole, is to include prevention and protection against

\footnotetext{
105 M. Sandy Hershcovis and Julian Barling, 'Towards a Multi-Foci Approach to Workplace Aggression: A Meta-Analytic Review of Outcomes from Different Perpetrators' (2010) 31 Journal of Organizational Behavior 24.

${ }_{106}$ Taylor-Baptiste (n 26) [47]; Taylor-Baptiste v Ontario Public Service Employee Union, (2014) 323 OAC 376 (Divisional Court).

${ }_{107}$ Taylor-Baptiste (n 26) [47] - [67].
} 
violence in the workplace in a range of legislative and other instruments. This should include occupational health and safety and workers' compensation legislation that applies to all workers, thus ensuring that the protections are mainstreamed. Advantages of integrating the right of all workers to protection against violence in labour legislation include a better and more uniform understanding of the existence of provisions, and an inclusionary approach that makes violence against all workers everybody's business. Parallel legislation targeting only violence against women may be more easily marginalized or ignored, relying on regulators rather than workplaces to ensure its adequate application. In a globalised labour market where inspectorates, particularly human rights inspectorates, are often underfunded and perceived as marginal to the workplace, it seems more likely that protections will apply effectively if employers, unions and all workers feel they benefit from protective legislation but also that they will be sanctioned if they themselves fail to protect workers or, worse, act as perpetrators of workplace violence.

It can be said that addressing violence that targets women at work requires reflection and interventions at the crossroads between occupational health and safety frameworks and frameworks designed to detect and address sexism and discrimination. To date, national and international regulators and researchers have not embraced a holistic view. In most discussions, issues have been addressed in silos: those interested in sexual violence lobby for specific remedies without consideration of the broader question regarding all forms of occupational violence and their determinants, while those interested in workers' health are blind to the gender dimensions of occupational violence in all its forms.

Criminal violence against women is disproportionately invisible because women don't report sexual violence. Sexual harassment is also hugely underreported, and when alternative recourse is available, as in jurisdictions where sexual harassment is included in the concept of bullying, the discriminatory dimension becomes even more invisible. ${ }^{108}$ When violence occurs in the workplace many jurisdictions do not disaggregate reports on violence in the workplace by gender, and domestic violence at work, including homicides, goes largely unreported in studies of workplace violence in many countries, including the UK. This invisibility of the gendered dimensions of occupational violence undermines the effectiveness of prevention strategies and discourages anti-discrimination initiatives. Addressing the occupational violence which all workers are exposed to is important, but it must not be done at

108 See Cox 'Sexual to Psychological Harassment' (n 35) and Casas Becerra (n 27). 
the expense of making visible the gendered and discriminatory dimensions of workplace violence.

Governments must be accountable. To enable men and women to participate equally in the labour market, it is necessary to ensure that they can get to work safely and work in safe workplaces where they will not be targets of occupational violence because they are workers or because of their gender. 